\title{
Commentary on "Expression of dopamine 2 receptor subtypes mRNA in clinically nonfunctioning pituitary adenomas"
}

\author{
Andrea Salmaggi · Sandro Lodrini
}

Received: 24 June 2011/Accepted: 28 June 2011/Published online: 6 August 2011

(C) Springer-Verlag 2011

In the paper by Su et al. [1], in this issue, expression of mRNA for the two subtypes of dopamine 2 receptor has been evaluated by RT-PCR in operative samples from 72 patients (21 with prolactinomas, 25 with gonadotropinoma, 21 with null cell adenoma, 3 with oncocytoma, and 2 with silent corticotroph adenoma). Two normal pituitaries were also assessed.

The results showed a lower expression of D2L and D2S mRNA in NFPAs as compared with prolactinomas, but a minority of the patients (21.6\%), mostly gonadotropinomas and null cell adenomas, displayed relatively high mRNA levels.

The very recently published study by Gabalec et al. [2] lends support to the observations of Su et al. confirming the preferential expression of D2R mRNA in gonadotropinomas, however, with significant interindividual variability.

The standard approach to the treatment of NFPAs consists of trans-sphenoidal surgery; however, the management of postoperative residual tumor is debated, and no evidence-based indications are present (with both watch and wait and radiotherapy and hormonal therapy options being present) [3].
The observations by Su and Gabalec support future prospective controlled studies aimed at evaluating the differential response to these treatment options (and possibly also to innovative molecules) [4] stratified according to DR2 mRNA expression.

\section{References}

1. Su Z, Wang C, Wu J, Jiang X, Chen Y, Chen Y, Zheng W, Zhuge $\mathrm{Q}$, Wu Z, Zeng Y Expression of dopamine 2 receptor subtype mRNA in clinically nonfunctioning pituitary adenomas. Neurol Sci 32 doi:10.1007/s10072-011-0701-6

2. Gabalec F, Beranek M, Netuka D, Masopust V, Nahlowsky J, Cesak T, Marek J, Cap J (2011) Dopamine 2 receptor expression in various pathological types of clinically non-functioning pituitary adenomas. Pituitary [Epub ahead of print]

3. Greenman Y, Stern N et al (2009) Non-functioning pituitary adenomas. Best Pract Res Clin Endocrinol Metab 23(5):625-638

4. Peverelli E, Olgiati L, Locatelli M, Magni P, Fustini MF, Frank G, Mantovani G, Beck-Peccoz P, Spada A, Lania A (2010) The dopamine-somatostatin chimeric compound BIM-23A760 exerts antiproliferative and cytotoxic effects in human non- functioning pituitary tumors by activating ERK1/2 and p38 pathways. Cancer Lett 288:170-176

\footnotetext{
A. Salmaggi $(\bowtie) \cdot S$. Lodrini

Fondazione IRCCS Istituto Neurologico Carlo Besta,

Via Celoria 11, 20133 Milan, Italy

e-mail: salmaggi@istituto-besta.it
} 